\title{
Trophic organization and fish assemblage structure as disturbance indicators in headwater streams of lower Sorocaba River basin, São Paulo, Brazil
}

\author{
Bruna Botti Cruz ${ }^{1}$, Fernanda Ayumi Teshima ${ }^{1}$ and Mauricio Cetra ${ }^{2}$
}

Studies that investigate the relationship patterns between environmental structure complexity and fish fauna provide crucial information to stream restoration efforts. In order to test the hypothesis that streams with more complex environmental structure sustain more diverse and functionally more complex fish communities we sampled fish fauna from Sorocaba River headwater stream reaches (SE - Brazil). Reaches represented two distinct treatments: (1) a simplified reach, characterized by unstable fine substrate, clay, deeper channel and higher water velocity and (2) structurally complex reaches, characterized by coarse substrate, with gravel, pebble, rock, stems and branches and leaves inside the channel, producing a diverse pattern of microhabitat, associated with sequences of pools, runs, and riffles. Both trophic structure and taxonomic composition varied significantly between treatments. Invertivorous trophic group exclusively occurred in structurally complex reaches, which also presented greater diversity and species richness. We suggest enhancing in-stream environmental structure that suffered simplification processes due to human impacts in order to reestablish fish communities and ecossistemic functioning.

Estudos que buscam investigar os padrões de relação entre a complexidade da estrutura ambiental e a fauna de peixes fornecem informações cruciais para os esforços de restauração de riachos. Para testar a hipótese de que riachos com estrutura ambiental mais complexa sustentam comunidades ícticas mais diversas do ponto de vista taxonômico e funcional, a ictiofauna de trechos de riachos de cabeceira do rio Sorocaba (SE - Brasil) foi amostrada, representando dois tratamentos distintos: (1) um trecho de riacho simplificado, caracterizado por substrato fino e inconsolidado, composto por areia e silte, curso d'água mais profundo, com maior velocidade e poucos elementos diversificadores da estrutura de habitat e (2) trechos de riacho estruturalmente complexos, com substrato de fundo composto por elementos irregulares como cascalho, rochas, seixos, troncos, galhos e restos de madeira, produzindo um padrão diverso de microhabitats, associados à sequências de poços, corredeiras e trechos rápidos. Tanto a estrutura trófica quanto a composição taxonômica foram distintas em relação aos dois tipos de riachos. O grupo trófico dos invertívoros ocorreu somente nos trechos estruturalmente mais complexos, que apresentaram também maior diversidade e riqueza de espécies. Sugere-se incrementar a estrutura ambiental de riachos que sofreram simplificação ambiental, devido à ação humana, a fim de promover a reestruturação da comunidade íctica e o funcionamento ecossistêmico.

Key words: Bioindicators, Environmental heterogeneity, Functional group.

\section{Introduction}

The diversity and richness of stream fishes can be influenced by many factors operating at multiple scales (Schlosser, 1987), including local/contemporary and regional/ historic levels (Marsh-Matthews \& Matthews, 2000; Hugueny et al., 2010). The distribution and abundance of populations on fish assemblages result from a combination of historical, evolutive and biogeographical processes, which produce local contemporary responses to environmental variation that also involves biological interactions with other species (Winemiller, 2010). It is expected that streams from the same basin have experienced the same historic, evolutive and biogeographic process, thus local and contemporary characteristics become more important to fish community's organization.

\footnotetext{
${ }^{1}$ Universidade Federal de São Carlos, Programa de Pós-Graduação em Diversidade Biológica e Conservação, Câmpus Sorocaba, $18052-780$ Sorocaba, SP, Brazil. brunabotti@yahoo.com.br(BBC); ferteshima@gmail.com (FAT).

${ }^{2}$ Universidade Federal de São Carlos, Departamento de Ciências Ambientais, Câmpus Sorocaba, 18052-780 Sorocaba, SP, Brazil. mcetra@ufscar.br
} 
Though close regions supposedly present less environmental structure variation compared to distant regions (Toepfer et al., 1998), in-stream habitat features might vary among nearby sites. One of the most influent in-stream diversifier elements source is the riparian zone vegetation, which provides leaves, branches and wood debris (Casatti et al., 2009). The combination of these elements yield complex microhabitat patterns that coupled with alternated mesohabitats as riffles, pools and runs, may sustain high species richness (Casatti et al., 2009).

The interception and release of terrestrial matter to aquatic ecosystems by riparian vegetation generate important consequences for stream fish, once it constitutes the main energy source for those systems (Pusey \& Arthington 2003; Tedesco et al., 2007), especially for unstable environments, as headwater streams (Schlosser, 1990). The length of food chains (i.e., number of trophic levels or trophic transfers) is determined by energy availability in biological communities (McHugh et al., 2010). In this context, studies that investigate the relationships between environmental filters and trophic groups are of great pertinence, once they supply information about communities functioning and might help to understand species response mechanisms to environmental simplification (Poff, 1997).

In order to obtain balance in communities functioning the presence of all fundamental trophic levels required to energy and nutrient cycling is essential (Terborgh et al., 2010). Typically species richness increases with stream size (Pease et al., 2012). Patterns of trophic diversity in stream fish assemblages are expected to be similar (Schlosser, 1987). In general, smaller streams, with low species richness, maintain less rich trophic levels when compared to streams of greater size. Whilst the stream size increases, resources and different niches become more available, thus allowing the coexistence of species from the same trophic level (Tedesco et al., 2007; Villéger et al., 2010). Therefore, the loss of one species to a certain trophic level in streams with high richness is less catastrophic, once the redundancy in energy cycling is elevated. Conversely, in upland small streams one species loss might represent the deletion of an entire component of the food chain, compromising ecosystem functioning.

Studies that explore those aspects of communities' structure and dynamic can detect patterns and improve our ability to predict responses of natural communities to environmental change (Pease et al., 2012) and might also contribute to restoration plans. Although its importance, this type of studies remain underexploited in Brazil and are considered promising topics for future research, along with other functional aspects (Casatti et al., 2012; Pease et al., 2012; Teresa \& Casatti, 2012). This is of great concern to southeastern Brazil, where the advance of agriculture, livestock and urban areas throughout the decades has resulted in many impacts to aquatic ecosystems and biodiversity (Uieda \& Motta, 2007). Therefore, in this study, we tested if headwater streams with the same historic, biogeographic and evolutive context, but different levels of habitat complexity, sustain similar fish assemblages structure and ecossistemic functioning (Gorman \& Karr, 1978).

\section{Material and Methods}

Study area. The studied streams were tributaries of the lower Sorocaba River, in the upper Paraná River basin, southeastern Brazil. The lower Sorocaba River drains 3,137 $\mathrm{km}^{2}$ at an average $1,028 \mathrm{~m}$ above sea level (Marciano et al., 2004; IPT, 2006). The climate in the basin is predominantly tropical with an annual rainfall of $1,428 \mathrm{~mm}$ and with dry winters (April to September). Maximum and minimum temperatures average are $26.6^{\circ} \mathrm{C}$ and $16.0^{\circ} \mathrm{C}$, respectively (Marciano et al., 2004). Each sample site consisted of a $80 \mathrm{~m}$ long reach, in first to fourth order streams (Fig.1A and B). Streams reaches were selected based on accessibility and aiming to include a diverse representation of physical habitat characteristics along gradients of riparian zone composition, stream width, mesohabitats and substrate composition.

Data sampling. Reaches with environmental structure considered more complex (TT1 - $1^{\text {st }}$ order $23^{\circ} 39^{\prime} 44^{\prime \prime} S$ $47^{\circ} 33^{\prime} 25^{\prime \prime} \mathrm{W}$; TT3 - $1^{\text {st }}$ order, $23^{\circ} 40^{\prime} 42^{\prime \prime}$ 'S 47 $32^{\circ} 1.96^{\prime \prime} \mathrm{W}$, and TT2 - $3^{\text {rd }}$ order, $23^{\circ} 40^{\prime} 30.01^{\prime \prime}$ 'S $47^{\circ} 32^{\prime} 45.06^{\prime \prime} W$; Fig. 1a and b) presented coarse substrate, with more than $60 \%$ of gravel, pebble, rock, stems and branches and leaves inside the channel, producing a diverse pattern of microhabitat associated with sequences of pools, runs and riffles. The banks of each margin were stable, without recent sediment losses signs. The riparian vegetation presented strata of different heights, resulting in a mixture of covered and lighted areas. The simplified reach (TC $-4^{\text {th }}$ order, $23^{\circ} 48^{\prime} 20.5^{\prime}$ 'S $47^{\circ} 25^{\prime} 50.9^{\prime \prime} \mathrm{W}$; Fig. 1a and b), presented unstable substrate, with sand and unconsolidated clay, deeper channel, around $70 \mathrm{~cm}$, and higher water velocity. Margin banks presented signs of recent sediment losses and around $50 \%$ of channel was uncovered by riparian vegetation canopy.

Reaches were investigated twice during the dry season in September, 2009 and October, 2010, except for TT1 and TC, sampled three times during the same period.

Fish collection was performed during daytime using a single upstream passage of electric fishing (stationary generator, Yamaha, model EF2600, $2.3 \mathrm{kVA}, 60 \mathrm{~Hz}$, linked to a current rectier), without containment nets upstream or downstream. All fishes were xed in $10 \%$ formalin, preserved in $70 \%$ ethanol after $72 \mathrm{~h}$, and identified to species with taxonomic keys and assigned to one of four trophic groups (herbivore-detritivore, omnivore, invertivore or carnivore, according to Lorion \& Kennedy, 2009) and based on previous studies (Abelha et al., 2001; Casatti et al., 2002; Oricolli \& Bennemann, 2006; Oyakawa et al., 2006). Vouchers were deposited at Museu de Zoologia, Universidade de São Paulo, and Departamento de Zoologia e Botânica, Universidade 


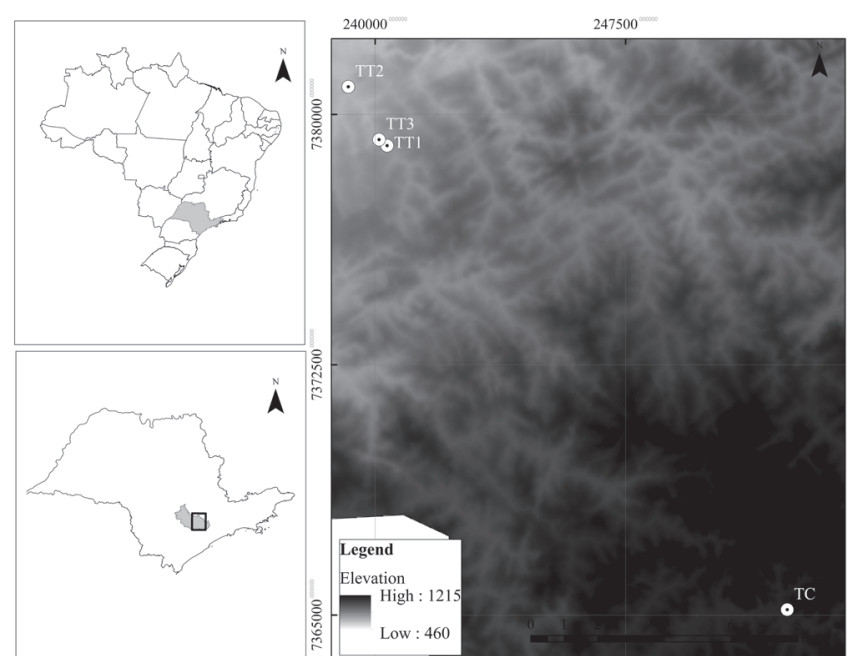

a)
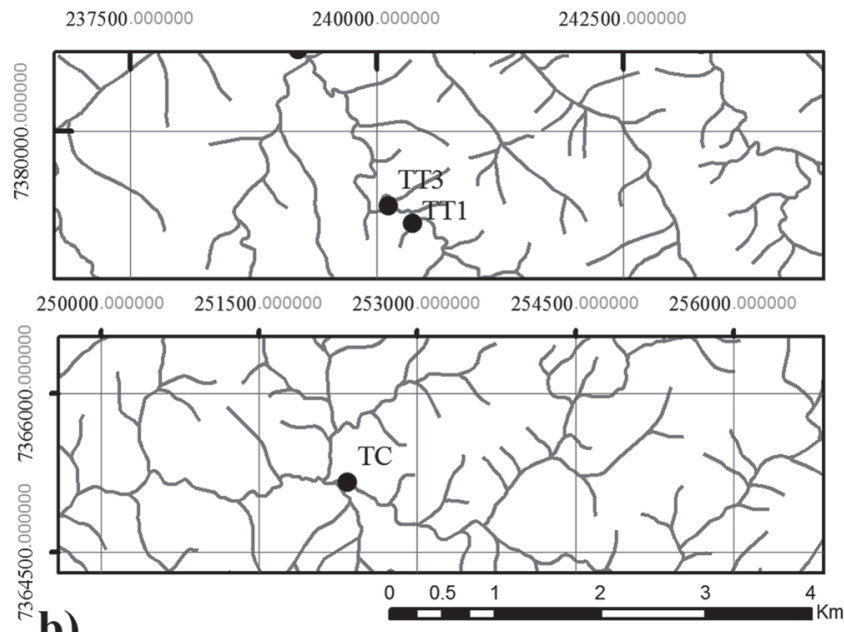

b)

Fig. 1. Map of the study area showing São Paulo State within Brazil (top left panel); Sorocaba River basin (shaded) and sample region (square) within São Paulo State (bottom left panel); and elevation profile and hydrography with position of the sampled sites (circles) in the sample region (right panel).

Estadual Paulista "Júlio de Mesquita Filho", câmpus de São José do Rio Preto, São Paulo, Brazil.

Data analysis. We used one-way ANOVA resampled without replacement (Gotelli \& Entsminger, 2012) to investigate the effects of reach environmental complexity on assemblage structure and functioning. The comparisons were made based on species and trophic groups' densities (individuals $/ \mathrm{m}^{2}$ ), as well as Shannon's (H'), Pielou's (J') and Margalef's (Mg) indices that were calculated using diversity modules available in the PAST ${ }^{\mathrm{TM}}$ ecological software package (Hammer et al., 2001).

We tested the significance of Pearson correlation coefficient in order to access relationships among certain diversity indices and trophic groups' density and answer the following questions i) is there an effect of carnivores density (i.e. predation) in assemblage richness? ii) Is the omnivore density independent from assemblage richness (i.e. we expected that more disturbed reaches present lower richness value and higher omnivore density)? iii) Do the aggregated distribution of invertivores affect assemblage equability? Relationships between environmental complexity and fish assemblage structure were evaluated with ordination methods. To ordinate reaches according to species composition and trophic groups a Non-Metric Multidimensional Scaling Analysis (NMDS) was performed on PAST ${ }^{\mathrm{TM}}$ statistical package (Hammer et al., 2001) using the Bray-Curtis similarity coefficient. The significance of the patterns provided by the NMDS was tested by a non-parametric Analysis of Similarity (ANOSIM) with 10,000 permutations (Hammer et al., 2001). Invertivore density was not considered in the analyses once this trophic group only occurred in the treatment group.

\section{Results}

A total of 429 individuals were collected, representing 16 species, 10 families and five orders. Organisms presented small body size (Length Standard $<15 \mathrm{~cm})\left(\overline{\mathrm{X}}_{\mathrm{LS}}=7.6 \mathrm{~cm} ; \mathrm{s}_{\mathrm{LS}}=5.4\right.$ $\mathrm{cm}$ ), except Gymnotus sylvius, Rhamdia quelen, and Hoplias malabaricus. Regarding richness and abundance characiforms and siluriforms were the most representative orders (Table 1).

Our results indicate that environmental structure simplification has a consistent effect on the taxonomic and functional structure of stream fish assemblages in the study area. Treatments showed statistically significant differences. Fish density varied significantly among reach types and was higher in more complex and diverse streams $(p=0.04)$. Species richness $(p=0.04)$, and consequently, diversity displayed the same pattern $(p=0.05)$. Conversely, reach types did not influence equability and trophic group densities (Table 2 and Fig. 2).

Our results did not completely meet our expectations as some predicted correlations were not statistically significant (Table 3). Carnivore density was positively correlated with species richness ( $p=0.02$ ), whereas omnivore density did not show significant correlations. On the other hand, invertivore density was negatively correlated with assemblage's equability $(p=0.03)$.

Non-metric multidimensional scaling ordinations of sampling sites (Fig. 3) supported the conclusions of ANOVA tests. Reaches with more complex environmental structure consistently grouped together in the multivariate space, forming a distinct group from the simplified reach when considering taxonomic $(p=0.008, \mathrm{R}=0.92)$ and functional structure ( $p=0.008, \mathrm{R}=0.86$ ).

\section{Discussion}

Results from this study suggest strongly that environmental simplification is important in controlling variation in suites of fish assemblage structure characteristics. Differences found in total density among reach types 
Table 1. Species list with respective abundances $\left(\mathrm{N}_{\mathrm{T}}\right)$ and trophic groups, herbivore-detritivore (Herb-Det), omnivore $(\mathrm{Omn})$, carnivore (Car) or invertivore (Inv), in the structurally complex streams (TT) and simplified stream (TC). Vouchers registered at the Museu de Zoologia, Universidade de São Paulo (MZUSP). Catalog numbers marked with na asterisk indicate vouchers registered at Departamento de Zoologia e Botânica, Universidade Estadual Paulista “Júlio de Mesquita Filho", câmpus de São José do Rio Preto (DZSJRP).

\begin{tabular}{|c|c|c|c|c|c|c|}
\hline Order/Family/Species & $\begin{array}{l}\text { Trophic } \\
\text { group }\end{array}$ & $\mathrm{TC}$ & TT1 & TT2 & TT3 & Vouchers \\
\hline \multicolumn{7}{|l|}{$\overline{\text { CHARACIFORMES }}$} \\
\hline \multicolumn{7}{|l|}{ Characidae } \\
\hline Astyanax eigenmanniorum (Cope, 1894) & Omn & 31 & 16 & 12 & 9 & 108306 \\
\hline Astyanax paranae Eigenmann, 1914 & Omn & - & 5 & 1 & 2 & 108316 \\
\hline Bryconamericus iheringii (Boulenger, 1887) & Omn & 1 & - & 30 & 10 & 108307 \\
\hline Hyphessobrycon bifasciatus Ellis, 1911 & Omn & 1 & 3 & - & - & 108312 \\
\hline $\begin{array}{l}\text { Oligosarcus paranensis Menezes \& Géry, } 1983 \\
\text { Crenuchidae }\end{array}$ & Car & - & - & 2 & 2 & 108300 \\
\hline $\begin{array}{l}\text { Characidium zebra Eigenmann, } 1909 \\
\text { Erythrinidae }\end{array}$ & Inv & - & 7 & - & - & $13645^{*}$ \\
\hline Hoplias malabaricus (Bloch, 1794) & Car & 2 & 1 & 1 & - & 108313 \\
\hline $\begin{array}{l}\text { CYPRINODONTIFORMES } \\
\text { Poeciliidae }\end{array}$ & & & & & & \\
\hline $\begin{array}{l}\text { Phalloceros cf. harpagos Lucinda, } 2008 \\
\text { GYMNOTIFORMES }\end{array}$ & Omn & 18 & 6 & 9 & 3 & 108310 \\
\hline Gymnotidae & & & & & & \\
\hline $\begin{array}{l}\text { Gymnotus sylvius Albert \& Fernandes-Matioli, } 1999 \\
\text { PERCIFORMES }\end{array}$ & Omn & 7 & 3 & - & 5 & 108314 \\
\hline Cichlidae & & & & & & \\
\hline $\begin{array}{l}\text { Geophagus brasiliensis (Quoy \& Gaimard, 1824) } \\
\text { SILURIFORMES }\end{array}$ & Omn & - & - & - & 1 & 108311 \\
\hline Callichthyidae & & & & & & \\
\hline $\begin{array}{l}\text { Callichthys callichthys (Linnaeus, 1758) } \\
\text { Loricariidae }\end{array}$ & Omn & - & 1 & - & - & 108319 \\
\hline $\begin{array}{l}\text { Hypostomus ancistroides (Ihering, 1911) } \\
\text { Heptapteridae }\end{array}$ & Herb-Det & 8 & 5 & 19 & 12 & 108309 \\
\hline Cetopsorhamdia iheringi Schubart \& Gomes, 1959 & Inv & - & 8 & - & 5 & 108318 \\
\hline Imparfinis schubarti (Gomes, 1956) & Inv & - & 63 & 83 & 25 & 108308 \\
\hline $\begin{array}{l}\text { Rhamdia quelen (Quoy \& Gaimard, 1824) } \\
\text { Trichomycteridae }\end{array}$ & Car & 2 & - & 2 & 4 & 108303 \\
\hline Trichomycterus iheringi (Eigenmann, 1917) & Inv & - & 4 & - & - & 106197 \\
\hline $\mathrm{N}_{\mathrm{T}}$ & & 70 & 122 & 159 & 78 & \\
\hline
\end{tabular}

contradict other studies, which reported higher density of fish in disturbed environments (Lorion \& Kennedy, 2009). The authors argument that this pattern is due to the increase of species with generalist trophic characteristics (Abes \& Agostinho, 2001; Casatti et al., 2009). In disturbed sites, where there is low availability of preferred food item, species with the flexible diets have advantages (Uieda \& Motta, 2007) and appear to be less vulnerable to the effects of deforestation (Lorion \& Kennedy, 2009). However, our results show that total density is higher in reaches with preserved physical structure of the stream environment, due to high invertivore density.

Species diversity and richness are also in contrast with other studies that provided some theoretical expectations regarding communities' structure in streams across environmental gradients. The simplified reach is a fourth order stretch and, according to the River Continuum Concept (Vanote et al., 1980), it is expected larger area and energy availability (Pease et al., 2012). Based on this concept, fish diversity and richness were expected to be greater in that reach, once there are more niches and species with different resource exploitation strategies (Vannote et al., 1980).
Table 2. ANOVA results for total fish density, trophic groups and species diversity for both groups of streams $\left(\mathrm{n}_{\mathrm{TC}}=3\right.$; $\left.\mathrm{n}_{\mathrm{TT}}=7\right) . \mathrm{F}_{\mathrm{obs}}=$ calculated value, $\overline{\mathrm{X}}_{\mathrm{Fsim}}=$ average of $\mathrm{F}$ after 1,000 resamples, $\mathrm{s}_{\mathrm{Fsim}}^{2}=$ variance of $\mathrm{F}$ after 1000 resamples and $\mathrm{p}=$ exact probability. $\mathrm{H}^{\prime}=$ Shannon Index, $\mathrm{J}^{\prime}=$ Pielou Index, $\mathrm{Mg}=$ Margalef Index, Car $=$ Carnivores, Herb-Det $=$ Herbivores-Detritivores, Omn $=$ Omnivores. The $*$ sign designates statistically significant values.

\begin{tabular}{lcccc}
\hline Variables & $\mathrm{F}_{\text {obs }}$ & $\overline{\mathrm{X}}_{\text {Fsim }}$ & $\mathrm{s}_{\text {Fsim }}^{2}$ & $\mathrm{p}$ \\
\hline Density (individuals $\left./ \mathrm{m}^{2}\right)$ & 7.37 & 1.38 & 6.29 & $0.04^{*}$ \\
$\mathrm{H}^{\prime}$ & 5.61 & 1.33 & 3.58 & $0.05^{*}$ \\
$\mathrm{~J}$ & 0.09 & 1.33 & 4.87 & 0.74 \\
$\mathrm{Mg}$ & 6.21 & 1.26 & 4.26 & $0.04^{*}$ \\
$\mathrm{Car}$ & 0.75 & 1.40 & 7.54 & 0.47 \\
Herb-Det & 3.17 & 1.35 & 13.01 & 0.14 \\
Omn & 1.55 & 1.19 & 3.01 & 0.26 \\
\hline
\end{tabular}

Nevertheless, this pattern did not occured. Thus, although the longitudinal effects are important to structure fish assemblages, they were not the main determinants of the differences found between reach types. Therefore, the 

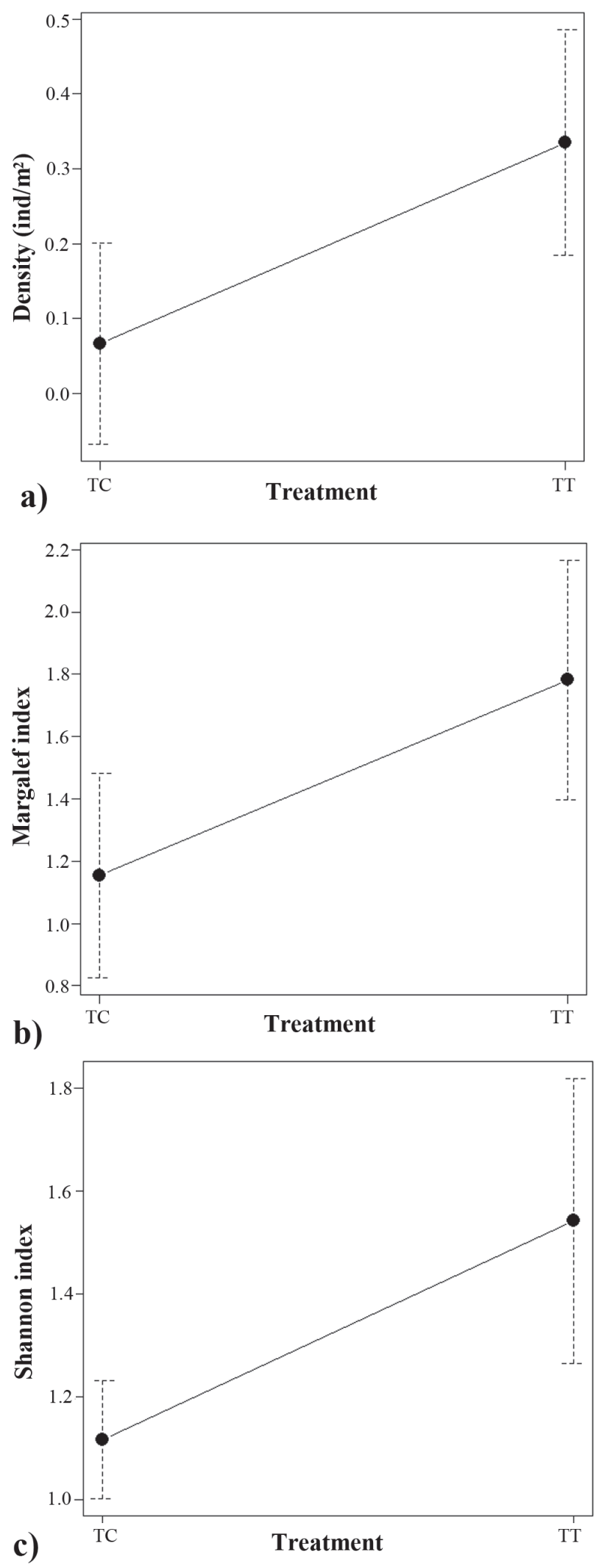

Fig. 2. Average values and confidence interval $\left(\mathrm{IC}_{95 \%}\right)$ of individuals' density, Shannon and Margalef Indices for each treatment, structurally complex streams (TT) and simplified stream (TC).
Table 3. Coefficients of the linear correlation $\left(\mathrm{r}_{\mathrm{obs}}\right)$ between carnivores' density and species richness (Car-S), omnivores density and species richness (Oni-S) and invertivores density and equitability (Inv-J'). $\overline{\mathrm{X}}_{\mathrm{rsim}}=$ average of $\mathrm{r}$ after 1000 resamples, $s_{\text {Fsim }}^{2}=$ variance of $r$ after 1000 resamples, $p=$ exact probability, ${ }^{*}=$ statistically significant values and $\mathrm{n}=$ sample size.

\begin{tabular}{lccccc}
\hline Variable & $\mathrm{r}_{\text {obs }}$ & $\overline{\mathrm{X}}_{\text {rsim }}$ & $\mathrm{s}_{\text {rsim }}^{2}$ & $\mathrm{P}$ & $\mathrm{n}$ \\
\hline Car-S & 0.67 & 0.006 & 0.111 & $0.02^{*}$ & 10 \\
Omn-S & 0.47 & -0.007 & 0.107 & 0.08 & 10 \\
Inv-J' & -0.77 & -0.026 & 0.158 & $0.03^{*}$ & 7 \\
\hline
\end{tabular}

variation was mainly due to differences in in-stream and margin banks variables. This conclusion is based on local habitat conditions and regional factors influence (Hoeinghaus et al., 2007), especially regarding environmental heterogeneity (Casatti et al., 2009; Dias \& Tejerina-Garro, 2010).

The geographic proximity inserts the four reaches in the same historical, biogeographical and evolutive context, albeit the local environmental impacts are from distinct sources and present different intensities. The simplified reach is located nearby crop, urban and landfill areas, aside the access road. These factors might be associated with riparian zone removal, resulting in less armored stream banks against erosion and sediment input mediation (Pusey \&Arthington, 2003), increasing sedimentation rates of the channel (Casatti et al., 2009). Reaches with more complex environmental structure did not suffer as much direct impacts, because they are not close to human activities. One of them, for example, is located inside a private property, what might constrain human access to the reach. Hence, each reach group is subject to distinct environmental pressures, meaning that the ecological processes and biotic interactions respond in distinct ways (Fialho et al., 2008) as observed for communities' structure and trophic organization.

The exclusive occurrence of invertivorous species in environmentally complex reaches is probably due to substrate diversity. Coarser substrate associated with allochthonous organic matter (e.g., large woody debris, leaf litter) favor invertebrate communities establishment, which sustain invertivorous species such as Imparfinis schubarti, Cetopsorhamdia iheringii, and Trichomycterus iheringi (Pagotto et al., 2011; Rosa et al., 2011). Characidium zebra, an invertivorous, stealth predator species, showed the same afore mentioned pattern. These species, among other from Heptapteridae (Pagotto et al., 2011), Trichomycteridae (Uieda \& Pinto, 2011) and Crenuchidae families (Braga \& Gomiero, 2009) might be considered specialized, once they are strongly subordinated to specific niches availability in the system. Thereby, changes in environmental conditions that alter specific niches may deeply affect those species (Villéger et al., 2010), as observed for the simplified reach. In this case, the sandy substrate represents a homogenous environment, precluding life litter and invertebrates accumulation, which 

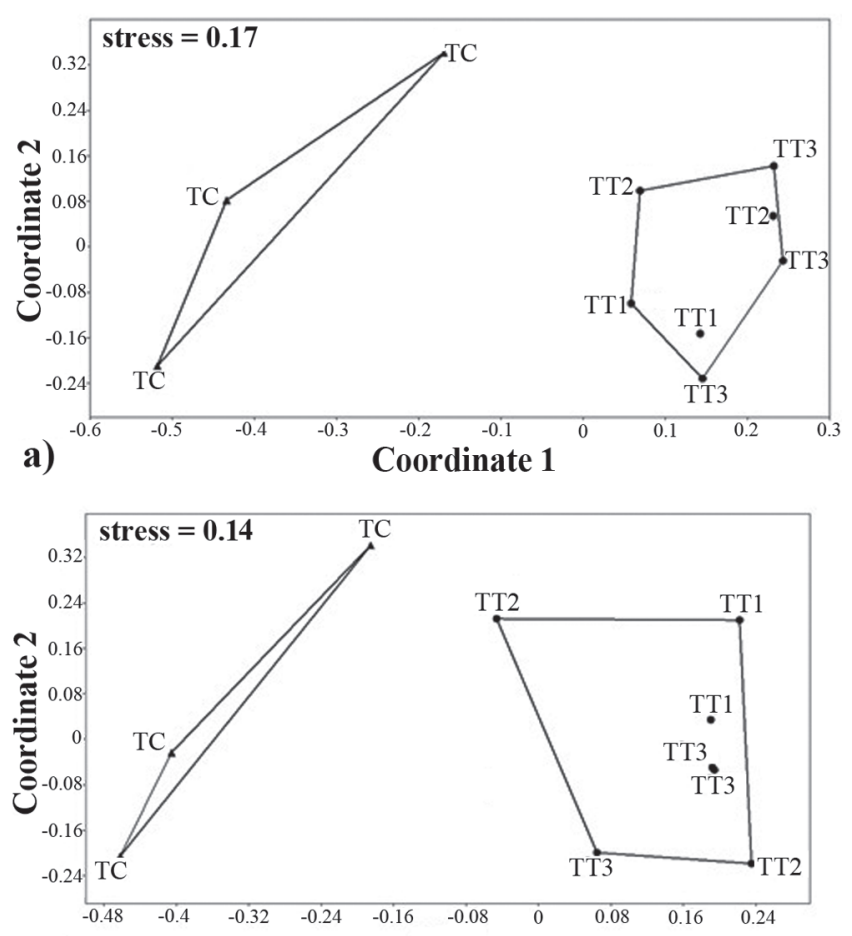

b)

Coordinate 1

Fig. 3. Projections of the Non-Metric Multidimensional Scaling (NMDS) and the smallest convex hulls that contain all data of the structurally complex streams (TT1, TT2 and TT3) and simplified stream (TC) according to a) taxonomic structure and $\mathbf{b}$ ) trophic groups.

are washed away (Casatti et al., 2009). In these environments, where food resources are highly variable, only species with opportunistic strategies and omnivorous diet, mid water swimmers that feed on drift items, such as Astyanax eigenmanniorum (Uieda \& Pinto, 2011), have enough resilience and resistance to persist, since these characteristics enhance their change of survivor (Pease et al., 2012). This suggests an important role for reach-scale filtering of trophic traits and species by geomorphological and hydrological characteristics as described by Poff (1997).

Invertivores and equability negative relation in structurally complex reaches might be associated to various invertivorous species in the same area and due to Imparfinis schubarti dominance in fish assemblages. The invertivorous species coexistence is a result of adequate resources amount, provided by the environment coupled with species' morphological and behavioral characteristics that differentiate minimally their niches, independently from species phylogenetic relations (Leal et al., 2011). For example, Imparfinis genus consists of a nocturnal substrate speculator, while Trichomycterus genus speculates during the day (Casatti, 2002). Whilst Characidium genus includes species that feed during the day, their feeding tactics are stealth predation (Casatti, 2002). The distribution of the environmental conditions that allow these species occurrence is highly aggregated along the stream channel. Those species are mainly restricted to riffles habitats, producing an aggregated distribution pattern and consequently low equability, as herein observed.

On the other hand, the positive relation between carnivores and richness can be explained by trophic cascade effects (Terborgh et al., 2010) of top down regulation (Tedesco et al., 2007), that increases richness through predator mediation. Top-predator carnivorous species (i.e., Hoplias malabaricus and Rhamdia quelen), reduce competition in lower levels species, maintaining population below their carrying capacity and enhancing coexistence (Novakowski et al., 2007; Tedesco et al., 2007).

The lack of invertivorous species in the simplified reach can be interpreted as a sign that community functioning is impaired (Villéger et al., 2010), once there is a lack of one component on the food chain. This suggests that energy distribution among food chain in the reach groups is not the same (Terborgh et al., 2010).

Based on the fact that communities functional characteristics reflect ecossistemic processes and/or ecosystem stability, through resistance and resilience (Villéger et al., 2010), we can assume that the simplified reach is disturbed and its integrity and health are long term compromised. The lack of biotic components diminishes its capacity to resist and recover from environmental disturbances (SER, 2004).

The information provided by trophic groups' analyses is essential to demonstrate the importance of an integrated approach of communities' structure in order to produce an accurate diagnosis. In certain cases, trophic groups comparisons are more advantageous than solely species richness and diversity analysis per se (Villéger et al., 2010), specially for communities with distinct species composition or with similar equability and richness values (Cunico et al., 2011). Therefore, species or trophic group quality (i.e., species functional role in community dynamics), might provide more accurate information about environmental integrity and realistic needs to support restoration actions.

Given our results, we can suggest two basic and urgent restoration actions for the simplified reach. First action involves in-stream recovery in order to increase mesohabitats and microhabitats complexity. Steams, wood debris, leaves and different sized rocks, arranged in various angles in channel's bottom, might enhance shelter availability without interfering in species dispersion (Cowx \& Welcomme, 1998). Same elements could be used to armor stream banks coupled with tree and shrub species utilization would diminish sediment input to the channel, responsible for smothering of coarse gravel beds (Sonoda et al., 2011). In this scenario, rockier substrate alternated with small impoundments and higher velocity flow would enhance stream's environmental heterogeneity (Casatti et al., 2009).

Second proposition relates to riparian zone conservation 
with minimum human interference, promoting natural regeneration and allowing it to fulfill its role as a buffer zone to aquatic system. In a long term, a well-structured riparian zone is capable of protecting the aquatic environment and preserving water quality from nearby region (Sonoda et al., 2011). In addition, it can provide allochthonous organic matter inputs (e.g., large woody debris, leaf litter, terrestrial insects) that serve as food and habitat for stream organisms, as fish communities (Pusey \& Arthington, 2003; Casatti et al., 2009). At last, it is essential to ensure that these streams are connected with preserved or less disturbed ones that might act as native species sources, favoring species dispersion and the establishment of long term populations (Sundermann et al., 2011).

In synthesis, our results indicate changes in fish assemblages with stream environmental homogenization pointed out by differences in species diversity, richness and trophic groups composition. The identification of specific biodiversity components that probably reflect stream disturbance may be useful for monitoring environmental quality of similar ecosystems. We suggest enhancing in-stream habitat complexity and conserve riparian zone vegetation, in order to increase resources and energy availability in the system, using components of the fish assemblages highlighted herein to monitor the success of such efforts. We believe that these results are of great importance to the management and restoration of freshwater ecosystems and to monitoring the health of upper watersheds.

\section{Acknowledgments}

This research was funded by $\mathrm{CNPq}$ and Universidade de São Carlos. SISBIO/IBAMA/MMA permit number 13352-1. Authors thank Luiz A. Manfré, Pedro G. K. V. Marques and Rodrigo C. Urban for assistance in the field work, landowners for allowing access to streams on their properties and Dr. Heraldo Britski from MZUSP for specimens taxonomic review.

\section{Literature Cited}

Abelha, M. C. F., A. A. Agostinho \& E. Goulart. 2001. Plasticidade trófica em peixes de água doce. Acta Scientiarum, 23: 425-434.

Abes, S. S. \& A. A. Agostinho. 2001. Spatial patterns in fish distributions and structure of the ichthyocenosis in the Água Nanci stream, Upper Paraná River basin, Brazil. Hydrobiology, 445: 217-227.

Apone, F., A. K. Oliveira \& J. C. Garavello. 2008. Composição da ictiofauna do rio Quilombo, tributário do rio Mogi-Guaçu, bacia do alto Paraná, sudeste do Brasil. Biota Neotropica, 8: 93-107.

Araújo, N. B. \& F. L. Tejerina-Garro. 2009. Influence of environmental variables and anthropogenic perturbations on stream fish assemblages, upper Paraná River, Central Brazil. Neotropical Ichthyology, 7: 31-38.

Begon, M., C. R. Towsend \& J. L. Harper. 2006. Interespecific competition. Pp. 227-265. In: Begon, M., C. R. Towsend \& J. L. Harper (Eds.). Ecology: from individuals to ecosystems. Oxford, Blackwell Publishing Ltda, 138p.
Braga, F. M. S. \& L. M. Gomiero. 2009. Alimentação de peixes na microbacia do Ribeirão Grande, Serra da Mantiqueira oriental, SP. Biota Neotropica, 9: 207-212.

Casatti, L. 2002. Alimentação dos peixes em um riacho do Parque Estadual Morro do Diabo, bacia do Alto rio Paraná, sudeste do Brasil. Biota Neotropica, 2: 1-14.

Casatti, L., C. P. Ferreira \& F. R. Carvalho. 2009. Grass-dominated stream sites exhibit low fish species diversity and dominance by guppies: an assessment of two tropical pasture river basins. Hydrobiology, 632: 273-283.

Castro, R. M. C. 1999. Evolução da ictiofauna de riachos sulamericanos: padrões gerais e possíveis processos causais. Oecologia Brasiliensis, 7: 139-155.

Cunico, A. M., J. D. Allan \& A. A. Agostinho. 2011. Functional convergence of fish assemblages in urban streams of Brazil ant the United States. Ecological Indicators, 11: 1354-1359.

Dias, A. M. \& F. L. Tejerina-Garro. 2010. Changes in the structure of fish assemblages in streams along an undisturbed-impacted gradient, upper Paraná River basin, Central Brazil. Neotropical Ichthyology, 8: 587-598.

Fialho A. P., L. G. Oliveira, F. L. Tejerina-Garro \& B. Mérona. 2008. Fish-habitat relationship in a tropical river under anthropogenic influences. Hydrobiology, 598: 315-324.

Gorman, O. T. \& J. R. Karr. 1978. Habitat structure and fish communities. Ecology, 59: 507-515.

Gotelli, N. J. \& G. L. Entsminger. 2012. EcoSim: Null Models Software for Ecology. Version 7.72. Acquired Intelligence, Inc. http: //www.uvm.edu/ ngotelli/EcoSim/EcoSim.html

Hammer, O., D. A. T. Harper \& P. D. Ryan. 2001. PAST: Paleontological Statistics Software Package for Education and Data Analysis. Palaeontologia Electronica, 4: 1- 9.

Hoeinghaus, D. J., K. O. Winemiller \& J. S. Birnbaum. 2007. Local and regional determinants of stream fish assemblage structure: inferences based on taxonomic vs. functional groups. Journal of Biogeography, 34: 324-338.

Hugueny, B., T. Oberdorff \& P. A. Tedesco. 2010. Community ecology of river fishes: a large-scale perspective. American Fisheries Society Symposium, 73: 1-34.

IPT - Instituto de Pesquisas Tecnológicas. 2006. Plano de Bacia da Unidade de Gerenciamento de Recursos Hídricos do Sorocaba e Médio Tietê (UGRHI 10). Relatório Técnico No 91265 205.CERISO/CBH-SMT/FEHIDRO.

Leal, C. G., N. T. Junqueira \& P. S. Pompeu. 2011. Morphology and habitat use by fishes of the Rio das Velhas basin in southeastern Brazil. Environmental Biology, 90: 143-157.

Lorion, C. M. \& B. P. Kennedy. 2009. Riparian forest buffers mitigate the effects of deforestation on fish assemblages in tropical headwater streams. Journal of Applied Ecology, 19: 468-479.

Marsh-Matthews, E. \& W. J. Matthews. 2000. Geographic, terrestrial and aquatic factors: which most influence the structure of stream fish assemblages in the midwestern United States? Ecology of Freshwater Fish, 9: 9-21.

McHugh, P. A., A. R. McIntosh \& P. G. Jellyman. 2010. Dual influences of ecosystem size and disturbance on food chain length in streams. Ecology Letters, 13: 881-890.

Novakowski, G. C., N. S. Hahn \& R. Fugi. 2007. Alimentação de peixes piscívoros antes e após a formação do reservatório de Salto Caxias, Paraná, Brasil. Biota Neotropica, 7: 149-154.

Oricolli, M. C. G. \& S. T. Bennemann. 2006. Dieta de Bryconamericus iheringii (Ostariophysi: Characidae) em riachos da bacia do rio Tibagi, estado do Paraná. Acta Scientiarum. Biological Sciences, 28: 59-63. 
Oyakawa, O. T., A. Akama, K. C. Mautari \& J. C. Nolasco. 2006. Peixes de riachos da Mata Atlântica nas Unidades de Conservação do Vale do Rio Ribeira de Iguape (1 ${ }^{\text {st }}$ ed.). São Paulo, Neotrópica, 201p.

Pagotto, J. P. A., E. Goulart, E. F. Oliveira \& C. B. Yamamura. 2011. Trophic ecomorphology of Siluriformes (Pisces, Osteichthyes) from a tropical stream. Brazilian Journal of Biology, 71: 469- 479.

Rosa, B. F. J. V., V. C. Oliveira \& R. G. A. Alves. 2011. Structure and spatial distribution of the Chironomidae community in mesohabitats in a first order stream at the Poço D'Anta municipal biological reserve in Brazil. Journal of Insect Science, 11: 1-13.

Schlosser, I. J. 1982. Fish community structure and function along two habitat gradients in a headwater stream. Ecological Monographs, 52: 395-414.

Schlosser, I. J. 1990. Environmental variation, life history attributes, and community structure in stream fish: implications for environmental management and assessment. Journal of Environmental Management, 14: 621-628.

Society for Ecological Restoration (SER) International, Grupo de Trabalho sobre Ciência e Política. 2004. Princípios da SER International sobre a restauração ecológica. [online] http: // www.ser.org

Sonoda, K. C., C. A. Vettorazzi \& E. M. M. Ortega. 2011. Relationship among landuse and composition of aquatic insects of four basins of São Paulo State. Neotropical Biology and Conservation, 6: 187-200.

Sundermann, A., S. Stoll \& P. Haase. 2011. River restoration success depends on the species pool of the immediate surroundings. Journal of Applied Ecology, 21: 1962-1971.

Tedesco, P. A., C. Ibañez, N. Moya, R. Bigorne, J. Camacho, E. Goitia, B. Hugueny, M. Maldonado, M. Rivero, S. Tomanová, J. P. Zubieta \& T. Oberdorff. 2007. Local-scale species-energy relationships in fish assemblages of some forested streams of the Bolivian Amazon. Comptes Rendus Biologies, 330: 255-264.
Terborgh, J., R. D. Holt \& J. A. Estes. 2010. Trophic cascades: what they are, how they work, and they matter. Pp. 1-18. In: Terborgh, J. \& J. A. Estes. (Eds). Trophic cascades: predators, prey, and the changing dynamics of nature. Washington, Island Press, 488p.

Toepfer, C. S., L. R. Williams, A. D. Martinez \& W. L. Fisher. 1998. Fish and habitat heterogeneity in four streams in the Central Oklahoma/Texas plains ecoregion. Proceedings of the Oklahoma Academy of Science, 78: 41-48.

Uieda, V. S. \& R. L. Motta. 2007. Trophic organization and food web structure of southeastern Brazilian streams: a review. Acta Limnologica Brasiliensia, 19: 15-30.

Uieda, V. S. \& T. L. F. Pinto. 2011. Feeding selectivity of ichthyofauna in a tropical stream: space-time variations on trophic plasticity. Community Ecology, 12: 31-39.

Vannote, R. L., G. W. Minshall, K. W. Cummins, J. R. Sedell \& C. E. Cushing. 1980. The river continuum concept. Canadian Journal of Fisheries and Aquatic Sciences, 37: 130-137.

Villéger, S., J. R. Miranda, D. F. Hernández \& D. Mouillot. 2010. Contrasting changes in taxonomic vs. functional diversity of tropical communities after habitat degradation. Ecological Applications, 20: 1512-1522.

Winemiller, K. O. 2010. Preface: Stream fish communities from patch dynamics to intercontinental convergences. Pp. 23-28. In: Guido, K. \& D. Jackson. (Eds.). Community ecology of stream fishes: concepts, approaches and techniques. Bethesda, American Fisheries Society, 664p.

Submitted August 3, 2012 Accepted November 22, 2012 by Norma S. Hahn

Published March 31, 2013 